an article (Sir Clement Price Thomas) devoted to carcinoma of the lung. All these summarize the present position very clearly, and it is noteworthy that all the authors foresee the eventual therapeutic solution in some form of chemotherapy. Prof. Haddow's summary of some of the fundamental experimental work is likely to be of interest to many readers of Nature, and it can be heartily recommended as giving in small compass an excellent idea of the main scientific approaches to the problem. It shows how we are beginning to regard the first ('initiation') stage of chemical carcinogenesis as being a combination of the chemical or its metabolites with one or more specific tissue constituents, and the second ('promoting') stage as one of continued proliferation or delayed maturation of the 'initiated' cells, with the final stage (neoplasia) emerging after protein deletion. One current view is that the cancer cell is such because it has lost key proteins essential for the control of growth. With the plethora of facts, attempts to arrive at a unifying hypothesis showing how the diverse and very numerous 'initiating' agents all have the same end result is becoming essential. What is the common factor in carcinogenesis induced by aromatic amines, polycyclic hydrocarbons, ionizing radiations, viruses, hormones and even prolonged tissue culture of some normal cells? This article adequately condenses much of the main evidence which has to be embraced in such a hypothesis. Attention is directed to the recrudescence of interest in tumour immunology, though without discussion. The present writer believes that future articles of this type will perforce discuss this subject more and more, for he has himself recently put forward evidence which supports Prof. Haddow's evaluation of its being "the most logical of all approaches".

\section{Radioiodinated Human Serum Albumin}

THE Radiochemical Centre (White Lion Road, Amersham, Bucks) can now supply human serum albumin which has been iodinated with radioactive iodine-131 to hospitals and research institutions in the United Kingdom in the same way as it supplies iodine-131. The product (Code No. $1 B .17$ ) is in an isotonic saline solution $(p \mathrm{H} 9 \cdot 0-9 \cdot 2)$, which is sterile and free from pyrogens, and is packed in $10-\mathrm{ml}$. rubber-capped multi-dose bottles. The specific activity is not less than $5 \mathrm{mc}$./mgm. albumin, and the minimum concentration is $100 \mathrm{mc} . / \mathrm{ml}$. solution. The protein is iodinated uniformly, and the amount of iodine present is less than 0.2 per cent of the weight of albumin. The active iodine is firmly bound to the protein molecules, and not more than 2 per cent of the total activity is in the form of free iodide at the time of dispatch. Particular care is taken to avoid denaturation, and the product cannot be distinguished from the original albumin by electrophoresis. The product is supplied in standard packages containing either $0.2 \mathrm{mc}$. ( $£ 3$ ) or $1.0 \mathrm{mc}$. (£5), larger quantities up to $5 \mathrm{mc}$. being available by arrangement ( $£ 5$ per me.). The human albumin is supplied by the Ministry of Health free of charge, and the price of the iodinated material includes only the cost of manufacturing and testing.

\section{Effects of Radiations on Human Populations}

IN an address delivered on January 11 to the California Institute of Technology, Dr. A. H. Sturtevant discussed the hazards of the increase in high-energy radiations to which human populations are already exposed as a consequence of atomand hydrogen-bomb tests and medical and other activities. He distinguished the two types of hazards : those to the exposed individuals and those to their descendants, and emphasized the appalling ignorance in which we are as to the long-term biological effects of radiations. Extrapolating from Drosophila to man, the present increase of radiation due to "fallout' from bomb tests would be responsible for the conception of 1,800 more individuals per year heterozygous for recessive lethals in the whole world. Dr. Sturtevant stressed that, in view of its social significance, scientists must try to get some idea of how much of what may be happening, and to how many people.

\section{School Nature Study Union}

THE first number of the fiftieth volume of School Nature Study, the journal of the School Nature Study Union, which appears in a new and attractive form, contains details of new activities by the Union (George Philip and Son, Ltd., London. 2s. 6d.). Besides the usual meetings and excursions which are organized in and around London, some provincial areas are showing interest in the Union's activities, and there is a possibility of a branch being formed in the Midlands. The journal contains some useful hints by John Sankey, assistant warden of the Juniper Hall Field Centre, on the ways of taming wild animals like foxes and badgers, an article by $\mathrm{E}$. T. Cluff on the behaviour of 'winter gnats', and other articles and reports on a number of conferences and meetings.

\section{Tanganyika Agricultural Corporation}

Tre work in Tanganyika of the Overseas Food Corporation is to be continued by a new organization, the Tanganyika Agricultural Corporation, which will come into being on March 30. It will operate in the areas taken over from the Overseas Food Corporation and will be financed for this purpose until September 1957 by a Colonial Development and Welfare grant from the British Government. The new Corporation will also be invited by the Government of Tanganyika to assist in carrying on the Rufiji Basin reconnaissance survey which is at present in progress under the ægis of the United Nations Food and Agriculture Organization. In particular, it will be asked to establish the trial farms that are being planned as part of this investigation. In addition, consideration is being given to other agricultural development projects which might with advantage be undertaken by the Corporation, by agreement with the Government.

\section{Physical Society's Exhibition}

THE Physical Society's annual Exhibition of Scientific Instruments and Apparatus will be held in the Royal Horticultural Society's New Hall, Greycoat and Elverton Streets, London, S.W.1, on the following dates: April 25, 10.30 a.m.-8 p.m. (Fellows and press only, 10.30 a.m.-2 p.m.); April 26 and 27, 10 a.m. -8 p.m. ; and April 28, 10 a.m. -5 p.m. The discourses this year will be as follows (each one at 6.15 p.m.) : April 25, the free electron as a tool in scientific research, by Mr. M. E. Haine (Associated Electrical Industries, Aldermaston); April 26, memory systems in the brain, by Prof. J. Z. Young (Department of Anatomy, University College, London); and April 27, recent developments in luminescence and its applications, by Dr. G. F. J. Garlick (Department of Physics, University of 